\title{
Modelling the labour market of minority ethnic groups
}

\author{
Maria Berrittella* \\ Università degli Studi di Palermo, Dipartimento di Scienze Economiche, Aziendali e Finanziarie, Viale delle Scienze, \\ Palermo 90128, Italy
}

Received 21 September 2011; received in revised form 1 December 2011; accepted 26 December 2011

Available online 10 January 2012

\begin{abstract}
This paper investigates the effects, in terms of labour and macroeconomic indicators, of closing the gap between the ethnic minority employment rate and the overall population rate using a computable general equilibrium modelling framework. The labour market has been integrated by indicators related to ethnicity, employment status and occupational class. The policy test has been designed for the UK. According to the results, the policy actions aimed to remove the barriers that contribute to the unemployment of the minority ethnic groups improve not only the employment and occupational status of these groups, but the effects are also positive in terms of aggregate employment, GDP, trade and welfare.

(C) 2012 Society for Policy Modeling. Published by Elsevier Inc. All rights reserved.
\end{abstract}

JEL classification: $\mathrm{C} 68 ; \mathrm{E} 24 ; \mathrm{J} 78$

Keywords: Computable general equilibrium analysis; Employment gap; Macroeconomic indicators; Minority ethnic groups

\section{Introduction}

We live in a world where exist groups of people that differ in terms of shared cultural heritage, race, religion, language, history, beliefs, customs, values or morals. The social and economic interaction of different minority ethnic groups is rather the rule than an exception. AfricanAmericans in the US, Turks in Germany, Indians in the UK are all examples of distinct ethnic groups in larger societies (Li, 2010).

\footnotetext{
* Tel.: +39 9123895319; fax: +39 91422988.
}

E-mail address: maria.berrittella@unipa.it 
Although the minority ethnic population is increasing accounting for more than 10 per cent of the total working age population in many countries, such as Denmark, Germany, UK and USA, the ethnic minorities face multiple barriers in the labour market. In fact, the minority ethnic groups are often over-represented in jobs which are low paid, require low minimal skill levels and have low security (Darity \& Mason, 1998). Also people in minority ethnic groups have higher unemployment rates than White people and are disadvantaged in access to professional-managerial position (Carlsson \& Rooth, 2007; Clark \& Drinkwater, 2007; Li \& Heath, 2009).

Different theoretical approaches have been applied to explain the existence of labour discrimination for the minority ethnic groups, such as the human capital theory (Becker, 1964; Borjas, 1985; Dustmann, 1993; Chiswick \& Miller, 1995), the social capital theory (Granovetter, 1973; Putnam, 2000; Lin, 2001) and the theory on reference groups and acculturation processes (i.e. Runciman, 1966; Kasinits et al., 2008). Furthermore, there is by now a large set of empirical studies on the labour situation of the minority ethnic groups (i.e. Belzil \& Poinas, 2010; Carliner, 2000; Carlsson \& Rooth, 2007; Chiswick \& Miller, 2002; Darity \& Mason, 1998; Dustmann \& Fabbri, 2003; Van Tubergen \& Kalmijn, 2005). From these theoretical and empirical studies, the main factors that result to contribute to the unemployment status of the minority ethnic groups can be summarized as follows: human capital (some ethnic groups have lower levels of education, skills and qualifications than the White population); geography (many ethnic minorities live in deprived areas with high unemployment); discrimination (unequal treatment by employers). Furthermore, within each ethnic group, women are more likely than men to be unemployed. Cultural factors, such as differences in preferences regarding family structure and women's roles in market versus home work, play a key role to explain the employment gap by gender (Antecol, 2000).

Labour discrimination towards minority ethnic groups has existed in society for decades and the problem has only started to get better in recent years. There has been a slow but steady reduction in the gap between White and ethnic minority employment rates and governments aim to completely eliminate this gap. In fact, they have included in their spending review policy improvements in educational performance, employment programmes and equal opportunities policies (Bourn, 2008; Kraal, Roosblad, \& Wrench, 2009; Welamedage, O’Donnell, Newcomb, \& Lambie, 2008). In more details, labour situation of the minority ethnic groups can be improved by assisting minority ethnic groups from the most deprived areas to move into or towards work, by stimulating unemployed individuals to start their own businesses, by helping employers to adopt an equality employment policy, and, indirectly, by providing adequate and appropriate social care services.

The governments have recognized that the labour policies for minority ethnic groups positively affect not only the well-being of these groups, but also the economy of the recipient countries. In fact, the prevalence of barriers to employment may limit the potential welfare and economic growth (Ayala \& Rodrìguez, 2007; Kraal et al., 2009; Zorlu, 2001).

However, the existing modelling frameworks on the labour situation of minority ethnic groups have been concentrated mainly on defining the casual relationship of the labour discrimination for minority ethnic groups (Antecol, 2000; Borjas, 1994; Carliner, 2000; Carlsson \& Rooth, 2007; $\mathrm{Li}, 2010$ ). Differently to them, developing a computable general equilibrium (CGE) model, called GTAP-MEG, main aim of this paper is to investigate the labour market and macroeconomic effects of closing the gap between White and ethnic minority employment rates. Despite its relevance, this question has not been systematically addressed in the existing literature.

A CGE model describes an economy in equilibrium with endogenously determined relative prices and quantities. Whereas most empirical approaches study the policy effects under a ceteris paribus condition, CGE models allow for other variables to change as well. They incorporate 
not only the labour market, but also other factor markets, goods markets and external trade markets. Interactions that take place between these different markets are taken into account. Thus, CGE models allow of evaluating the effects of exogenous shift in the labour force on wages and employment as well as on macroeconomic indicators, such as real GDP, trade balance and welfare. An assessment of the usefulness of CGE models for policy analysis can be found in Borges (1986). Furthermore, there are by now some empirical studies on labour market transmission and on migration using CGE models, but these models are not appropriate for the policy analysis of the labour situation of the minority ethnic groups. If on the one hand, the existing CGE analysis on labour transmission does not include the modelling of the minority ethnic groups (Agénor, Nabli, Yousef, \& Jensen, 2007; Naudé \& Coetzee, 2004; Winchester \& Greenaway, 2007); on the other hand, migration refers to foreign labour and has been modelled by labour bilateral flows from one country to another (Shimada, 2005; Weyerbrock, 1995). But minority ethnic groups are domestic labour and workers are native in the countries they live, and not immigrants from other countries, for this, differently to the previous studies, in GTAP-MEG the labour market has been modelled to include ethnicity, employment status and occupational class.

The policy experiment has been designed for the UK, which has a complete data set on minority ethnic groups. The effects of closing the gap between the ethnic minority employment rate and the overall population rate are positive in terms of labour and macroeconomic indicators. In fact, there are improvements in the employment status and access to the highest occupational class for the minority ethnic groups. Also the aggregate employment, GDP, trade and welfare increase.

The paper is organized as follows: the second section reports the theoretical and empirical literature on the labour situation of the minority ethnic groups including upstream review of what can be done to reduce unemployment; the third section describes the GTAP-MEG model; the fourth section reports data calibration; the fifth section discusses the policy design and results; finally, the last section reports concluding remarks.

\section{Literature review}

Different theoretical approaches have been applied to explain the existence of labour discrimination for the minority ethnic groups.

The most prominent approach among economists and sociologists is the human capital theory, which places great emphasis on the relevance of education, skills, experience, and language fluency for access to and advancement in the labour market (Becker, 1964; Borjas, 1985; Chiswick \& Miller, 1995; Dustmann, 1993).

The social capital theory, while acknowledging the importance of human capital, places greater emphasis on the resources embedded in the social relationships and the community structure (Granovetter, 1973; Putnam, 2000; Lin, 2001). The information shared among family and friends (bonding social capital) is of limited use in finding a job, whereas that offered by friends of friends (bridging social capital) may provide access to a wider range of opportunities, particularly, if the friends of friends are in different or higher level occupations, hence linking social capital.

A third theory on reference groups and acculturation processes helps to explain the changing fortunes of minority ethnic groups (Runciman, 1966; Kasinits et al., 2008). The first generation may be poorly educated and multiply disadvantaged, but they have the drive, tenacity and perseverance, which gives them the determination to overcome hardships, and are willing to do poorly paid jobs with long and unsocial hours, jobs usually shunned by the majority group. They may feel that they are doing equally well as other immigrants and better than their compatriots in the home country. As they stay longer, particularly their sons and daughters in the second generation, 
their horizons may grow broader and their aspirations higher. We may thus find first-generation immigrants to have similar or even lower levels of unemployment than the second-generation (since they are more willing to accept menial jobs), but would expect the latter to have greater access to more advantaged social positions that offer economic security, financial stability and career advancement (Li \& Heath, 2009).

There is by now a large set of empirical studies reporting evidence on the casual relationship of the high unemployment rate for the minority ethnic groups. If on the one hand, the unemployment rate of the White people may be correlated to the business cycles of an economy, with the unemployment rate that rises during a recession period; on the other hand, the high unemployment rate of the minority ethnic groups finds reason mainly in the presence of labour discrimination. In fact, numerous studies have been focused on the presence of discrimination in employment on black-white and male-female earnings and occupational disparities showing that employers tend to favour one group over another in the recruitment, retention and promotion rejecting candidates from minority ethnic groups in favour of White applicants even when they have the same skills (Carlsson \& Rooth, 2007; Darity \& Mason, 1998; Li, Devine, \& Heath, 2008; Li, 2010). However, there are initiatives, for example the campaign 'Racial Equality Means Business' in the UK, that help employers to adopt an equality employment policy to reduce the labour discrimination of the minority ethnic groups by an accreditation procedure that guarantee the minority ethnic groups to have their job applications evaluated in a non-discriminatory way (Bourn, 2008; Kraal et al., 2009).

Other empirical studies have been concentrated on the ethnic earnings differentials between first and second generation (Borjas, 1994; Dustmann, 1993) and on the causal relationship between language skills and the employment of immigrants (Carliner, 2000; Chiswick \& Miller, 2002; Dustmann \& Fabbri, 2003; Van Tubergen \& Kalmijn, 2005). The employment rates of minority ethnic groups have increased largely due to improvements in their educational attainment confirming that schooling investment is the main determinant for the reduction of the gap in permanent employment. In paid work there has been also an improvement in the social class of most ethnic groups (Belzil \& Poinas, 2010; Clark \& Drinkwater, 2007; Colding, 2006).

Also governments are including in their spending review policy the closing of the gap between White and ethnic minority employment rates, through improvements in educational performance and employment programmes (Bourn, 2008; Kraal et al., 2009; Welamedage et al., 2008). For example, by the mentoring programme, funded by the central government in Denmark, unemployed women have been helped to gain employment. The programme includes participation to language course, writing job applications, job interview practices, and establishing contacts with potential employers and professional networks. In the UK a "Deprived Areas Fund" exist for the labour integration of the minority ethnic groups with the highest level of worklessness.

An applied labour market policy to combat unemployment is to stimulate unemployed individuals to start their own businesses. Such policy leads to increases in self-employment, in particular, in the number of own-account workers. This policy is successful when the formerly unemployed individuals remain in employment for a longer period of time and also when they contribute to reduce unemployment not only by creating their own jobs, but also by hiring new employees (Clark \& Drinkwater, 2000; Congregado, Golpe, \& Carmona, 2010). Also Georgarakos and Tatsiramos (2009) find that individuals tend to enter entrepreneurship from unemployment or inactivity and they are more likely to exit towards employment in the wage sector, suggesting that entrepreneurship represents for them an intermediate step from non-employment to paid employment. However, individuals with low fluency in the language of the recipient countries, and recent immigrants, are less likely than other members of ethnic minorities to be self-employed. 
Finally, the success of the labour policies to improve the employment and occupational status of the minority ethnic groups will be guaranteed if the governments also ensure social policies oriented to the principles of equity and fairness to address needs and concerns of vulnerable minority families and individuals to prevent marginalization and exclusion by adequate and appropriate social care services (Barn, Sinclair, \& Ferdinand, 1997).

\section{Methodology}

To assess the systemic, general equilibrium effects of increasing employment rates for minority ethnic groups, a CGE model, called GTAP-MEG, has been used.

The GTAP-MEG model is a refinement of the original GTAP model, which is a comparative static, multi-commodity and multi-region CGE model with the assumptions of perfect competition, market equilibrium and open economy. As the mathematical structure of the GTAP model is very complex including a large number of equations that would become too much long to discuss here, this section aims to provide a concise description of the original GTAP model and to discuss its refinements. However, for a more complete description of the original GTAP model, see Hertel (1997) and Adams (2005).

\subsection{Consumption}

On the consumption side, the economy is modelled by a representative household in each region $r$, whose Cobb-Douglas utility function allocates expenditures between private consumption $(C)$, government consumption $(G)$ and savings expenditure $(S)$ as follows:

$$
U_{r}=C_{r}^{\alpha_{C, r}} G_{r}^{\alpha_{G, r}} S_{r}^{\alpha_{S, r}}
$$

with $\alpha_{C, r}, \alpha_{G, r}$ and $\alpha_{S, r}$ income shares and $\alpha_{C, r}+\alpha_{G, r}+\alpha_{S, r}=1$.

The constrained optimizing behaviour of the household in region $r$ for private consumption is represented by a non-homothetic constant difference of elasticity (CDE) expenditure function for the set of goods and services. A Cobb-Douglas sub-utility function is employed for government spending. In this case the expenditure shares are constant across all commodities. Private and government consumption are split in a series of alternative composite Armington aggregates (Armington, 1969).

\subsection{Production}

On the production side, the producers receive payments for selling consumption goods to the private households and the government, intermediate inputs to other producers and investment goods to the savings sector. Under the zero profit assumption, these revenues must be precisely exhausted on expenditures for intermediate inputs and primary factors of production. The nested production technology exhibits constant returns to scale and every sector produces a single output. The technology is simplified by employing the constant elasticity of substitution (CES) functional form (Fig. A.1):

$$
y_{i, r}=\left(\sum_{j=1}^{n} \theta_{j} x_{j, r}^{1-(1 / \sigma)}\right)^{\sigma /(\sigma-1)}
$$


where, in region $r, y_{i, r}$ is the production of the good $i, x_{j, r}$ is the input $j, \theta_{j}$ is a non-negative parameter, with $\sum_{j=1}^{n} \theta_{j}=1$, and $\sigma$ is the elasticity of substitution.

Both intermediate and final products from different regions are considered to be imperfectly substitutable with each other (Armington, 1969). All factor inputs (land, labour, capital, natural resources) are assumed to be fully employed and immobile across regions. Capital and labour are perfectly mobile across sectors and, hence, they earn the same market return regardless of where they are employed; land and natural resources are sluggish to adjust and their returns may differ across sectors.

\subsection{Savings and investment}

Savings are exhausted on investment and capital markets are assumed to be in equilibrium only at the global level. If savings exceed investments for one country, then it has a trade surplus; otherwise, it has a trade deficit. A hypothetical world bank collects savings from all regions and allocates investments so as to achieve equality of changes in expected future rates of return:

$$
\Delta \eta_{r}=\Delta \eta
$$

where $\Delta \eta_{r}$ and $\Delta \eta$ are the percentage change, respectively, in region's rate of return and global rate of return.

\subsection{Taxation}

Every economy includes government interventions. Private households and the government not only spend their available income on consumption goods, but also pay taxes to the regional household. In the case of the government, taxes consist of consumption taxes on commodities. In the case of private household, taxes consist of consumption taxes and income tax net of subsidies. The accounting relationships of these two agents therefore include taxes as additional expenditures. This is captured by the distinction between market prices and agent's prices inclusive of tax. Also firms have to pay taxes to the regional household. These value flows represent taxes on intermediate inputs and production taxes net of subsidies. Trade generated tax revenues and subsidy expenditures are computed in a manner analogous to the ones which are being raised by policy instruments used in the domestic market. The only difference is that now the tax or subsidy rates are defined as the ratio of market prices to world prices. If there is an import tax (subsidy), the market price is higher (lower) than the world price, so that the power of the ad valorem tax is greater (smaller) than one. In the case of an export tax (subsidy), the market price lies below (above) the world price and the power of the ad valorem tax is smaller (greater) than one. All taxes levied in the economy always accrue to the regional household.

\subsection{GTAP-MEG model}

The GTAP-MEG model includes refinements of the labour market. In the original GTAP model, the total labour supply is fixed exogenously and this is equivalent to the assumption of full employment in all countries/regions of the world. This assumption follows the neoclassic approach. But the full employment assumption for labour in most CGE models is problematic, because it is inconsistent with empirical evidence that has shown the existence of a relation between labour supply and the real wage (Agénor et al., 2007; Naudé \& Coetzee, 2004; Winchester \& 
Greenaway, 2007). For this, in GTAP-MEG, a labour supply curve for region $r$ has been modelled as follows:

$$
S_{r}=a_{r}-\frac{b_{r}}{w_{r}}
$$

where $S_{r}$ is the labour supply, $w_{r}$ is the real wage, $a_{r}$ is an asymptote, which can be interpreted as the maximal potential amount of available labour force, and $b_{r}$ is a positive parameter.

Furthermore, GTAP-MEG includes variables related to ethnicity, employment and occupational class for the UK. In fact, the modelling of the labour market of minority ethnic groups has implied the change of the production structure (Fig. A.2).

In more details, now for the production of the commodity $j$ in the labour nest, the firm will have the labour demand differentiated by minority ethnic groups $\left(E_{1, j}, E_{2, j}, \ldots, E_{n, j}\right)$. This implies that there will be a number of labour demands equal to the number of minority ethnic groups. There is no substitution between minority ethnic groups, if firm $j$ increases the labour demand, then it will increase the labour demand of the minority ethnic groups $i$ with equal percentage change. The labour demand function is:

$$
L_{j}^{E}=\min \left\{E_{1, j}, E_{2, j}, \ldots, E_{n, j}\right\}
$$

The minority ethnic labour demand is differentiated in occupational classes $\left(C_{1, j}, C_{2, j}, \ldots, C_{n, j}\right)$ combined by using the CES functional form as follows:

$$
L_{j}^{C}=\left(\sum_{i=1}^{n} C_{i, j}^{1-(1 / \rho)}\right)^{\rho /(\rho-1)}
$$

where $\rho$ is the elasticity of substitution between occupational class.

The assumptions in Eqs. (5) and (6) find evidence in the analysis by Zorlu (2001) and Kahanec (2006).

In order to code the employment status of the minority ethnic groups, the GTAP-MEG model specifies the relation between labour supply $\left(S_{i}\right)$ and the real wage $\left(w_{i}\right)$ for the minority ethnic group $i$ as follows:

$$
S_{i}=a_{i}-\frac{b_{i}}{w_{i}}
$$

where $a_{i}$ is an asymptote, which can be interpreted as the maximal potential amount of available labour force, and $b_{i}$ is a positive parameter.

The unemployment rate $\left(u_{i}\right)$ for the minority ethnic group $i$ is modelled as follows:

$$
u_{i}=1-\frac{S_{i}}{a_{i}}
$$

\section{Data calibration}

In the CGE models, a set of equations translates the structure of an economy and describes the behaviour of all agents and the equilibrium conditions of all markets. A calibration procedure fixes the parameters for the model's equations (called benchmark equilibrium) and, then the model can be solved for an alternative equilibrium associated with any changed policy regime. A comparison between the alternative and the benchmark equilibrium makes it possible to assess effects on allocation and income distribution. 


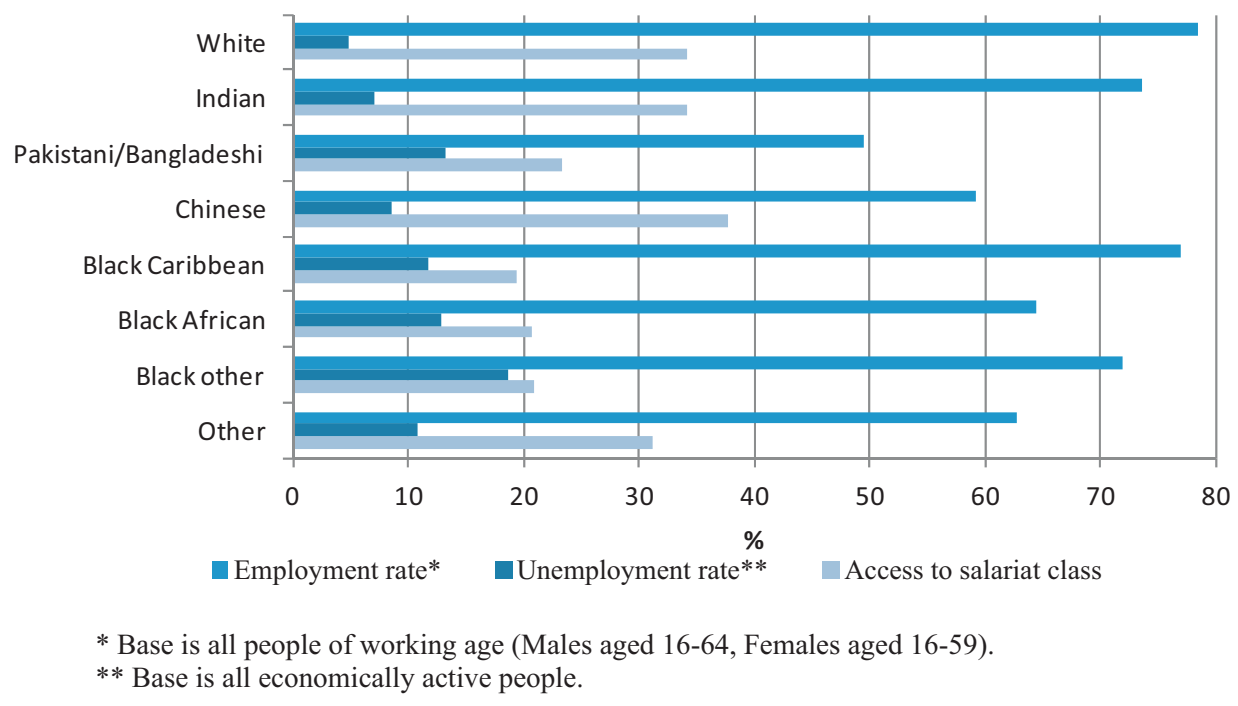

Source: Elaborations from ONS(2005).

Fig. 1. Proportions being employed, unemployed and access to salariat class by ethnicity in the UK. *Base is all people of working age (males aged 16-64, females aged 16-59). **Base is all economically active people.

Source: Elaborations from ONS(2005).

The GTAP-MEG model is calibrated for the year 2001 using two data sets: (i) the GTAP data base, version 6; (ii) the Annual Population Survey.

The GTAP data base, version 6, contains the 2001 world economy data. It is a cross-section data of international trade flows and national input-output tables. All the information in the data base is reported in values converted to US dollars. The behavioural parameters utilized in the GTAP model are described in Dimaran (2006). There are four sets of behavioural parameters in GTAP data base: (i) elasticities of substitution, in both consumption and production; (ii) transformation elasticities, that determine the degree of mobility of primary factors across sectors; (iii) the flexibilities of regional investment allocation; (iv) consumer demand elasticities.

The Annual Population Survey in the UK reports the data of the last Census for the year 2001 and is publicly available by the Office for National Statistics (ONS, 2005). Ethnicity has been coded in eight categories: White, Indian, Pakistani and Bangladeshi, Chinese, Black Caribbean, Black African, Black other and Other. Furthermore, two occupational class have been coded: (i) "salariat", which includes the professional and managerial class and (ii) "not salariat", which includes the intermediate and working class. The elasticity of substitution between the occupational classes has been assumed equal to 1.5 (Zorlu, 2001; Kahanec, 2006).

\section{Policy design and results}

The minority ethnic groups have higher unemployment rates, lower employment rates and access to salariat class than White people, as shown in Fig. 1, which reports the main labour indicators for the UK. However, ethnic minorities are not a homogenous group. Mainly, Indians, Chinese and Black Caribbeans perfom better than the other minority ethnic groups. Black African and Black other groups are less likely to be employed in the salariat class. 


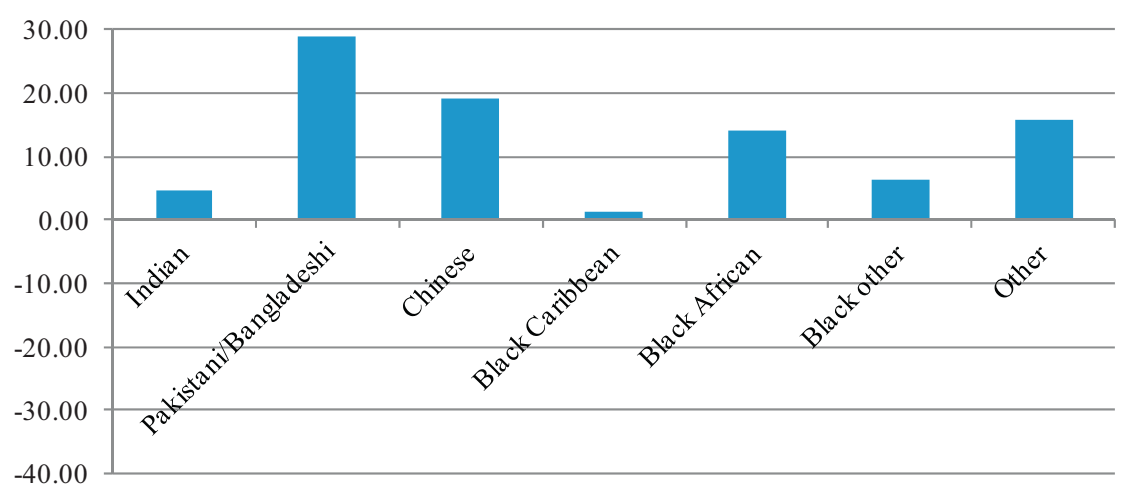

Fig. 2. Employment gap.

As the UK government's aim is to completely eliminate the employment gap between the ethnic minorities and the overall population, the policy test includes the closing of this gap, that is, about 13 percentage points. Fig. 2 shows that the employment gap is particularly substantial for Pakistani and Bangladeshi (more than 28 percentage points); whereas, it is very small for Black Caribbeans (less than 1.5 percentage points). If the employment gap decreases, then the unemployment rate decreases; in particular, the higher the employment gap, the higher the unemployment rate reduction (Fig. 3).

Furthermore, the reduction of the unemployment rate yields an excess in labour supply and also leads to real wages decreases (Fig. 4). The decrease of the real wage is slightly more substantial for the non salariat class than for the salariat class. Lower real wages lead to an increase in labour demand and aggregate employment (almost 4\%). The minority ethnic groups also benefit from the closing of the employment gap in terms of occupational class, because the access to the salariat class increases, as shown in Fig. 5.

In macroeconomic terms, the increase of the employment leads to increase the output and, hence, the effect on the real GDP is positive. In fact, as Fig. 6 shows, almost all the components of the GDP increase, except the investment demand. This is because minority ethnic groups are mainly employed in the distribution, transport, hotels and restaurants industry (in average about 30 per cent) and public services (in average about 35 per cent). Both real exports and imports

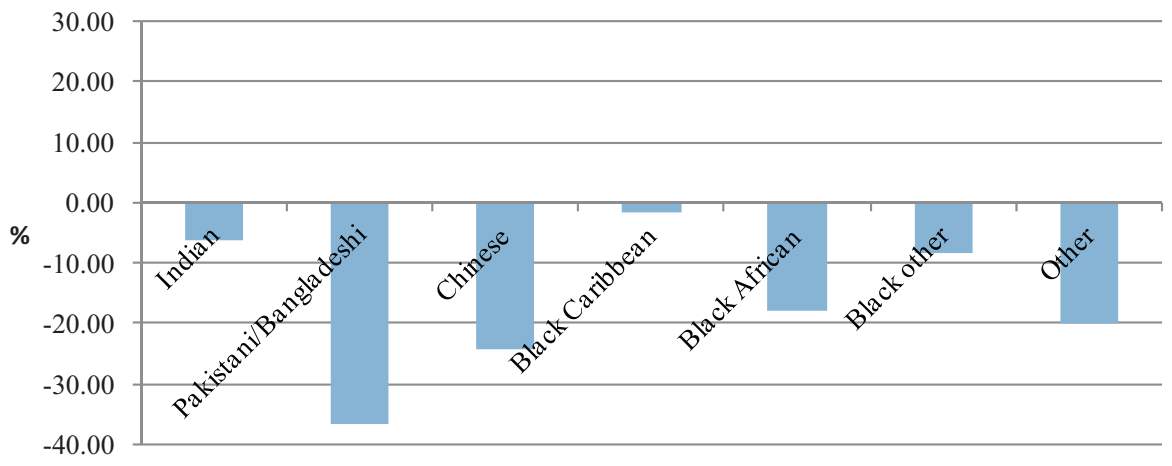

Fig. 3. Unemployment rate (percentage change w.r.t. benchmark equilibrium). 


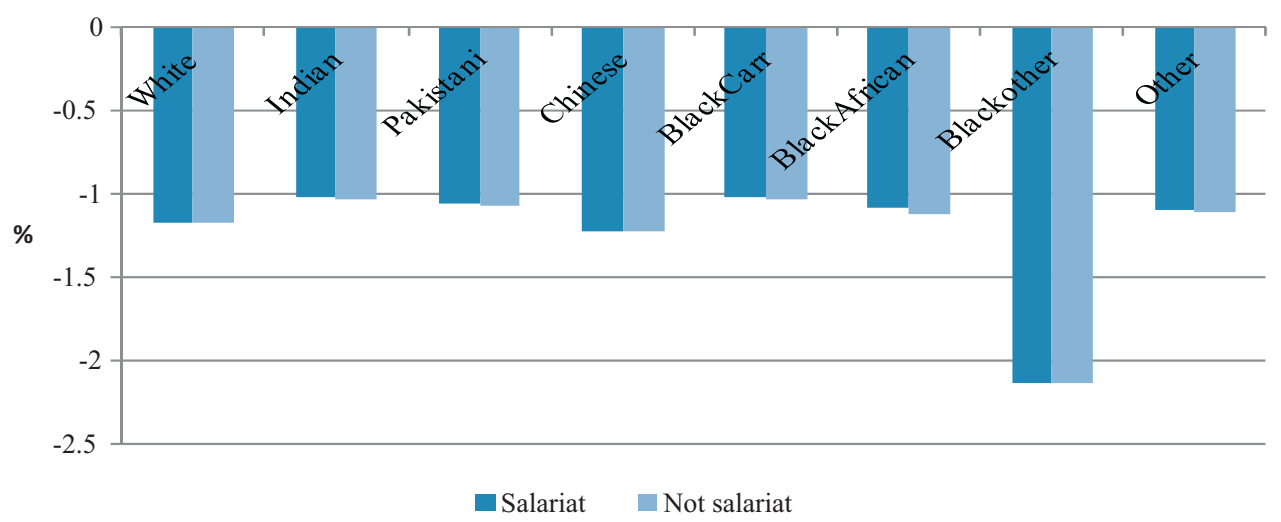

Fig. 4. Real wages (percentage change w.r.t. benchmark equilibrium).

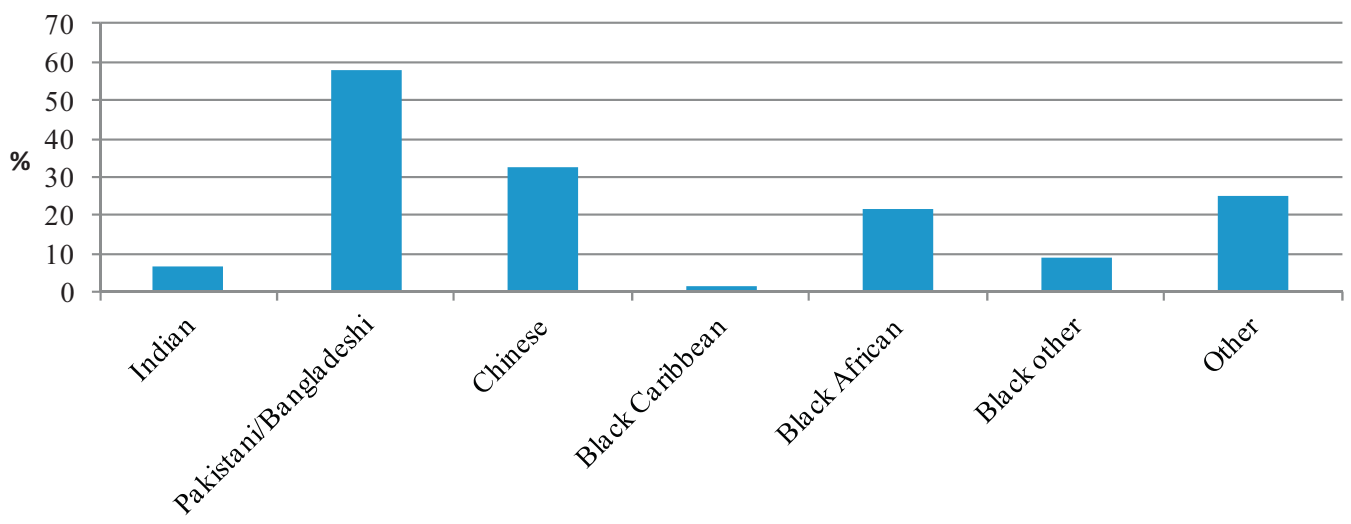

Fig. 5. Access to salariat class (percentage change w.r.t. benchmark equilibrium).

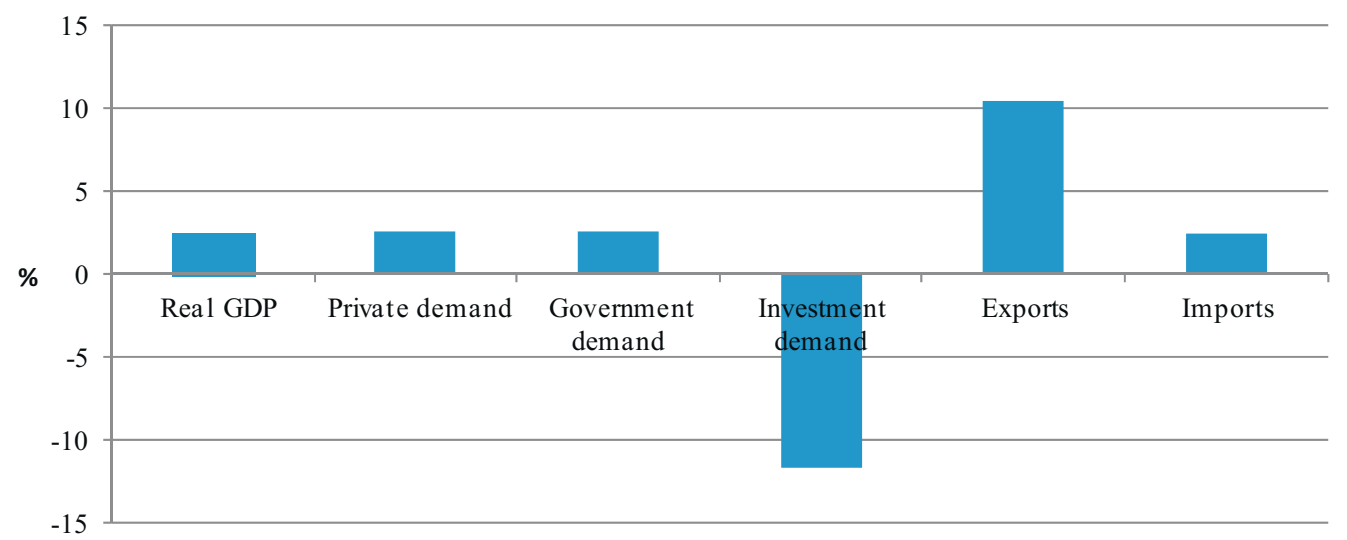

Fig. 6. Real GDP and its components (percentage change w.r.t. benchmark equilibrium). 


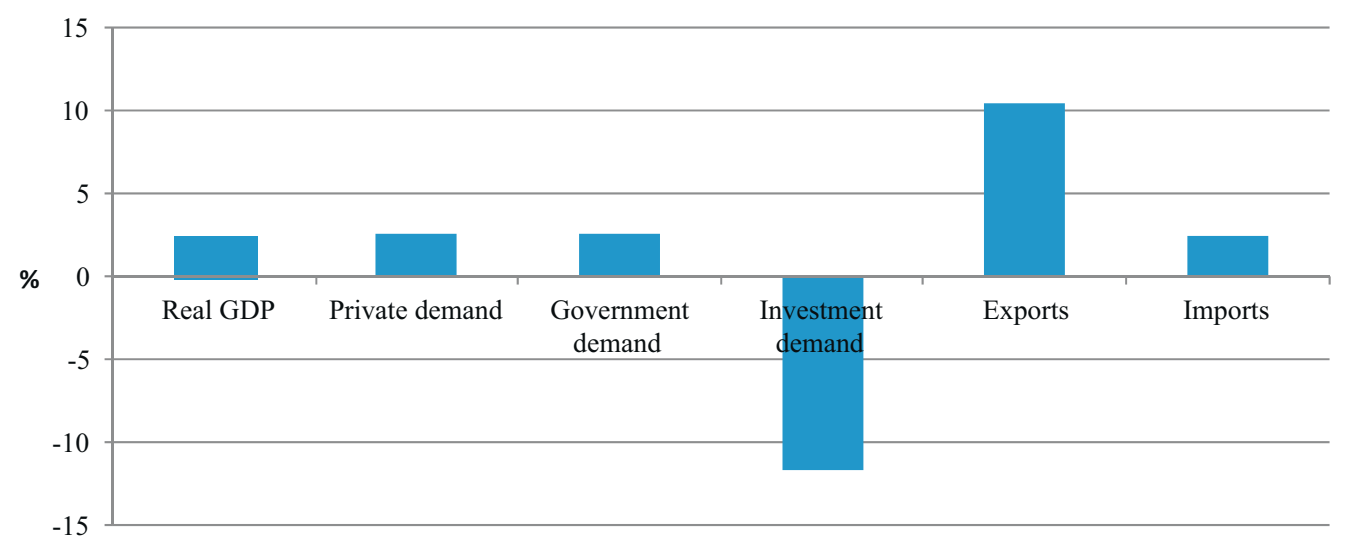

Fig. 7. Welfare and its decomposition (change w.r.t. benchmark equilibrium).

increase leading to trade gains. The effects on welfare change include the contributions in terms of endowment change, allocative efficiency and trade (Fig. 7). All these contributions yield welfare gains, but the contribution to welfare change in terms of endowment change, that is almost $60 \%$, is more substantial than the others.

\section{Conclusions}

Today the objective that no one should be disadvantaged in their employment prospects because of their ethnicity is become the target of every government, which aims to eliminate the employment gap between the ethnic minorities and the overall population. Thus, this paper has investigated the effects of increasing the employment rates for ethnic minorities using a computable general equilibrium analysis.

The GTAP-MEG model has been developed in order to include minority ethnic groups, that have been differentiated on the basis of their occupational class and employment status. The model allows of understanding the interactions between macro and micro-variables for the analysis of labour situation of the minority ethnic groups. In fact, it provides information to policymakers in terms of macro-variables such as GDP, welfare and unemployment, as well as in terms of micro-variables, such as wages, employment and occupational status per minority ethnic group.

The policy test has been designed for the UK. According to the results, the policies aimed to remove the barriers that contribute to the unemployment of the minority ethnic groups improve not only the well-being of these groups (unemployment reduction, better occupational status), but also the economy of the recipient country has benefits. In fact, the effects on the macroeconomic variables, such as aggregate employment, GDP, trade and welfare, are positive.

This paper provides to the policy-makers not only a quantitative analysis, in terms of amount of change in the market labour and macroeconomic indicators, but also a qualitative analysis, because the results are useful for understanding the conditions and directions of labour policy actions aimed to close the employment gap for minority ethnic groups also in other countries with a distribution of the ethnic minorities similar to the UK. 


\section{Acknowledgements}

This work was financially supported by the Ministero dell'Istruzione, dell'Università e della Ricerca (Rome, Italy). Research support from the Institute for the Social Science, University of Manchester, is also gratefully acknowledged. The opinions expressed here are those of the author, who remains solely responsible for errors and omissions.

\section{Appendix A.}

See Figs. A.1 and A.2.

\section{Production structure in the CGE model}

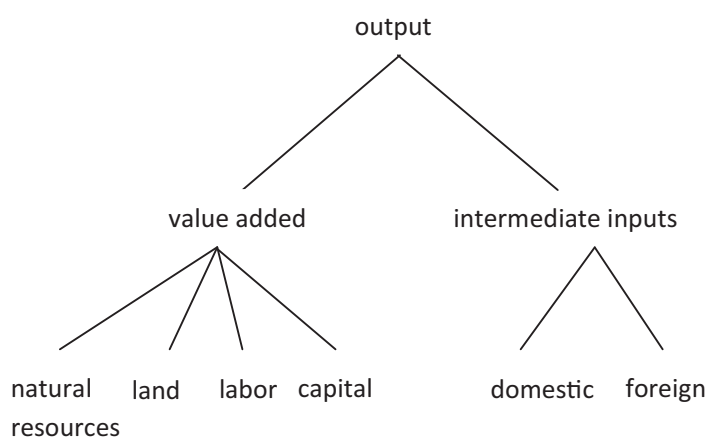

Fig. A.1. Production structure in the original GTAP model.

\section{Production structure in the original GTAP model}

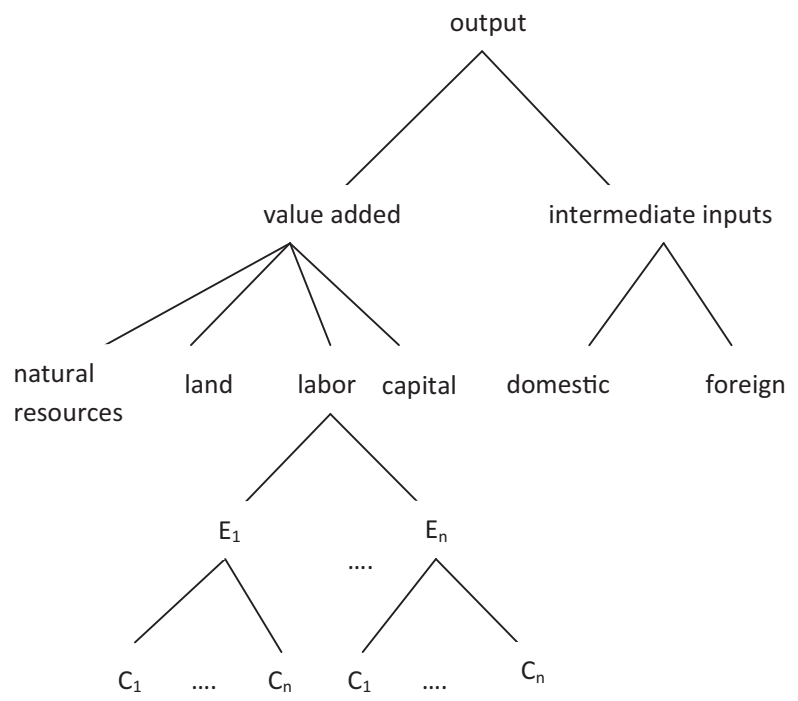

Fig. A.2. Production structure in the GTAP-MEG model. 


\section{References}

Adams, P. D. (2005). Interpretation of results from CGE models such as GTAP. Journal of Policy Modeling, 27, 941-959.

Agénor, P., Nabli, M. K., Yousef, T., \& Jensen, H. T. (2007). Labor market reforms, growth, and unemployment in labor-exporting countries in the Middle East and North Africa. Journal of Policy Modeling, 29, 277-309.

Antecol, H. (2000). An examination of cross-country differences in the gender gap in labor force participation rates. Labour Economics, 7, 409-426.

Armington, P. A. (1969). A theory of demand for products distinguished by place of production. IMF Staff Papers, 16 , 159-178.

Ayala, L., \& Rodrìguez, M. (2007). Barriers to employment and welfare dynamics: Evidence from Spain. Journal of Policy Modeling, 29, 237-257.

Barn, R., Sinclair, R., \& Ferdinand, D. (1997). Acting on principle, an examination of race and ethnicity in social services provision to children and families. London: BAAF.

Becker, G. (1964). Human capital: A theoretical and empirical analysis, with special reference to education. New York: Columbia University Press.

Belzil, C., \& Poinas, F. (2010). Education and early career outcomes of second-generation immigrants in France. Labour Economics, 17, 101-110.

Borges, A. (1986). Applied general equilibrium models: An assessment of their usefulness for policy analysis. $O E C D$ Economic Studies, 7, 7-43.

Borjas, G. (1985). Assimilation, changes in cohort quality, and the earnings of immigrants. Journal of Labour Economics, 3, 463-489.

Borjas, G. (1994). Long-run convergence of ethnic skills differentials: The children and grandchildren of the great migration. Industrial and Labor Relations Review, 47, 553-573.

Bourn, J. (2008). Increasing employment rates for ethnic minorities. In Report. London: National Audit Office.

Carliner, G. (2000). The language ability of US immigrants: Assimilation and cohort effects. International Migration Review, 34, 158-182.

Carlsson, M., \& Rooth, D. (2007). Evidence of ethnic discrimination in the Swedish labor market using experimental data. Labour Economics, 14, 716-729.

Chiswick, B., \& Miller, P. (1995). The endogeneity between language and earning: International analysis. Journal of Labour Economics, 13, 246-288.

Chiswick, B., \& Miller, P. (2002). Immigrant earnings: Language skills, linguistic concentrations and the business cycle. Journal of Population Economics, 15, 31-57.

Clark, K., \& Drinkwater, S. (2000). Pushed out or pulled in? Self-employment among ethnic minorities in England and Wales. Labour Economics, 7, 603-628.

Clark, K., \& Drinkwater, S. (2007). Ethnic minorities in the labour markets: Dynamics and diversity. London: Joseph Rowntree Foundation.

Colding, B. (2006). A dynamic analysis of educational progression of children of immigrants. Labour Economics, 13, $479-492$.

Congregado, E., Golpe, A. A., \& Carmona, M. (2010). Is it a good policy to promote self-employment for job creation? Evidence from Spain. Journal of Policy Modeling, 32, 828-842.

Darity, W., Jr., \& Mason, P. (1998). Evidence on discrimination in employment: Codes of color, codes of gender. Journal of Economic Perspectives, 12, 63-90.

Dimaran, B.V. (2006). Global trade, assistance and application: The GTAP 6 Data Base. Technical paper, Center for Global Trade Analysis, Purdue University.

Dustmann, C. (1993). Earnings adjustments of temporary migrants. Journal of Population Economics, 6, $153-158$.

Dustmann, C., \& Fabbri, F. (2003). Language proficiency and labour market performance of immigrants in the UK. Economic Journal, 113, 695-717.

Georgarakos, D., \& Tatsiramos, K. (2009). Entrepreneurship and survival dynamics of immigrants to the U.S. and their descendants. Labour Economics, 16, 161-170.

Granovetter, M. (1973). The strength of weak ties. American Journal of Sociology, 78, 1360-1380.

Hertel, T. W. (1997). Global trade analysis modeling and applications. Cambridge University Press.

Kahanec, M. (2006). The substitutability of labor of selected ethnic groups in the US labor market. IZA Discussion Paper, No. 1945.

Kasinits, P., Mollenkopf, J., Waters, M., \& Holdaway, J. (2008). Inheriting the city: The children of immigrants come of age. New York: Russell Sage Foundation. 
Kraal, K., Roosblad, J., \& Wrench, J. (2009). Equal opportunities and ethnic inequality in European labour markets. Amsterdam: Amsterdam University Press.

Li, Y. (2010). The labour market situation of minority ethnic groups in Britain and the US. EurAmerica, 40, $259-309$.

Li, Y., \& Heath, A. (2009). Struggling onto the ladder, climbing up the rungs: Employment status and class position by minority ethnic groups in Britain (1972-2005). In J. Stillwell, P. Norman, C. Thomas, \& P. Surridge (Eds.), Population, employment, health and well-being. Springer.

Li, Y., Devine, F., \& Heath, A. (2008). Equality group inequalities in education, employment and earnings: A research review and analysis of trends over time. Manchester: The Equality and Human Rights Commission.

Lin, N. (2001). Social capital. Cambridge University Press.

Naudé, W., \& Coetzee, R. (2004). Globalisation and inequality in South Africa: Modelling the labour market transmission. Journal of Policy Modeling, 26, 911-925.

ONS (2005) Focus on ethnicity. http://www.ons.gov.uk/ons/publications/re-reference-tables.html?edition=tcm\%3A7750846.

Putnam, R. (2000). Bowling alone: The collapse and revival of American community. New York: Simon \& Schuster.

Runciman, W. (1966). Relative deprivation and social justice. London: Routledge \& Kegan Paul.

Shimada, A. (2005). Foreign worker participation in labor markets and the economy's welfare. Journal of Policy Modeling, $27,355-362$.

Van Tubergen, F., \& Kalmijn, M. (2005). Destination-language proficiency in cross-National perspective: A study of immigrant groups in nine western countries. American Journal of Sociology, 110, 1412-1457.

Welamedage, L., O’Donnell, A., Newcomb, H., \& Lambie, E. (2008). Closing the ethnic employment gap in the North East. Centre for Public Policy: Northumbria University.

Weyerbrock, S. (1995). Can the European Community absorb more immigrants? A general equilibrium analysis of the labor market and macroeconomic effects of East-West migration in Europe. Journal of Policy Modeling, 17, 85-120.

Winchester, N., \& Greenaway, D. (2007). Rising wage inequality and capital-skill complementarity. Journal of Policy Modeling, 29, 41-54.

Zorlu, A. (2001). Ethnic minorities in the UK: Burden or benefit? ISER Working Paper Series, 2001-14. 